\title{
Farewell to Tradition? Presenting Archaeology after the Digital Turn
}

\author{
Monika Stobiecka
}

\section{OVERVIEW}

The last 20 years mark a period of transformation from a traditional model of displaying archaeology to a more immersive model supported by digital and virtual media. The traditional model has generally used glass cases accompanied by extensive texts to inform visitors, whereas the immersive model employs digital media, tablets, virtual reality, and augmented reality to attract and engage a wide audience. In light of the recent enthusiasm for the latter, however, one must ask whether such immersive exhibitions are merely superficial means to make public institutions more attractive without having a meaningful impact on audience engagement. Polish archaeological museums provide interesting sites through which to explore this predicament. Here, digital upgrades are generously financed by national funds, so the traditional model of the archaeological museum in Poland is currently almost absent. In this short review, I aim to discuss one of the most interesting examples of temporary digital archaeological exhibitions organized between 2014 and 2019 in the Polish capital of Warsaw. I investigate its potential to engage audiences, ultimately concluding that it managed to create an interesting counterweight to traditional displays and respond to the drawbacks of new digital exhibitions through novel aesthetics and alternative archaeological storytelling.

Keywords: archaeological exhibition, archaeological museum, Polish archaeology, archaeological heritage, digital exhibition, temporary exhibition

Despite the constant and quick development of new technologies in the service of heritage, the digital turn in museums has not contributed to novel forms of storytelling in obvious ways (Copplestone and Dunne 2017), nor has it lessened museums' typical reliance on visual communication (Classen and Howes 2006; Favro 2013; Geismar 2018). Many digital exhibitions-and the narratives they offer-are still tied to nondigital structures (Copplestone and Dunne 2017; Perry 2015). For example, lengthy texts on panels-typical for a traditional, contextual model of a display (Vergo 1989) —are now presented on digital tablets (Kidd 2014). Given the excitement about digital exhibitions, in many cases the only revolution we see is a change of medium orchestrated by the museums' IT departments. One must ask whether such displays are merely superficial means to make public institutions seem more attractive and progressive. Are they simply conveying the same stories and failing to make use of any new possibilities born of the digital turn in archaeological museums?

Polish archaeological displays provide interesting sites through which to explore these multilayered questions. In the following short review, I aim to describe and evaluate the digitally mediated temporary display Treasures of Peru: The Royal Tomb at Castillo de Huarmey, at the State Ethnographic Museum in Warsaw in 2018. I claim that, first of all, the success of this exhibition lies in the rejection of a pattern established in Poland for digital museums; second, the display offers a new way of understanding the entanglement of the digital and material in the archaeological museum; and third, the curators of the exhibition successfully escape the usual solution, in which the digital is imposed on an analog narrative.

\section{DIGITAL "BOOM" IN POLISH MUSEUMS}

Poland offers an interesting ground on which to examine digital displays. Since 2004, when the country joined the European Union and was able to apply for special funds devoted to the development of cultural infrastructure, Poles have built or rearranged about 100 multimedia museums and/or exhibitions. The pioneering example of the best digital exhibition, according to most Polish museum scholars (Kowal and Wolska-Pabian 2019), is the Warsaw Rising Museum, an institution that opened in 2004. The inauguration of this museum stands as the beginning of the Polish "museum boom," resulting in an intensive pattern of opening new museums and exhibitions. The Warsaw Rising Museum forged a type of "narrative display" that is common to these new institutions (Folga-Januszewska and Kowal 2019) and characterized by extensive use of varied multimedia (videos, audio recordings, digital tablets, visualizations, simulations, reconstructions) that "give voice" to and engage the material artifacts in a presented storyline. Multimedia are arranged in dimmed spaces, and they invite audiences to become immersed in past events and histories. The director of the Warsaw Rising Museum explained that the

Advances in Archaeological Practice 8(3), 2020, pp. 313-318

(1) The Author(s), 2020. Published by Cambridge University Press on behalf of Society for American Archaeology. This is an Open Access article, distributed under the terms of the Creative Commons Attribution licence (http://creativecommons.org/licenses/by/4.0/), which permits unrestricted re-use, distribution, and reproduction in any medium, provided the original work is properly cited. 


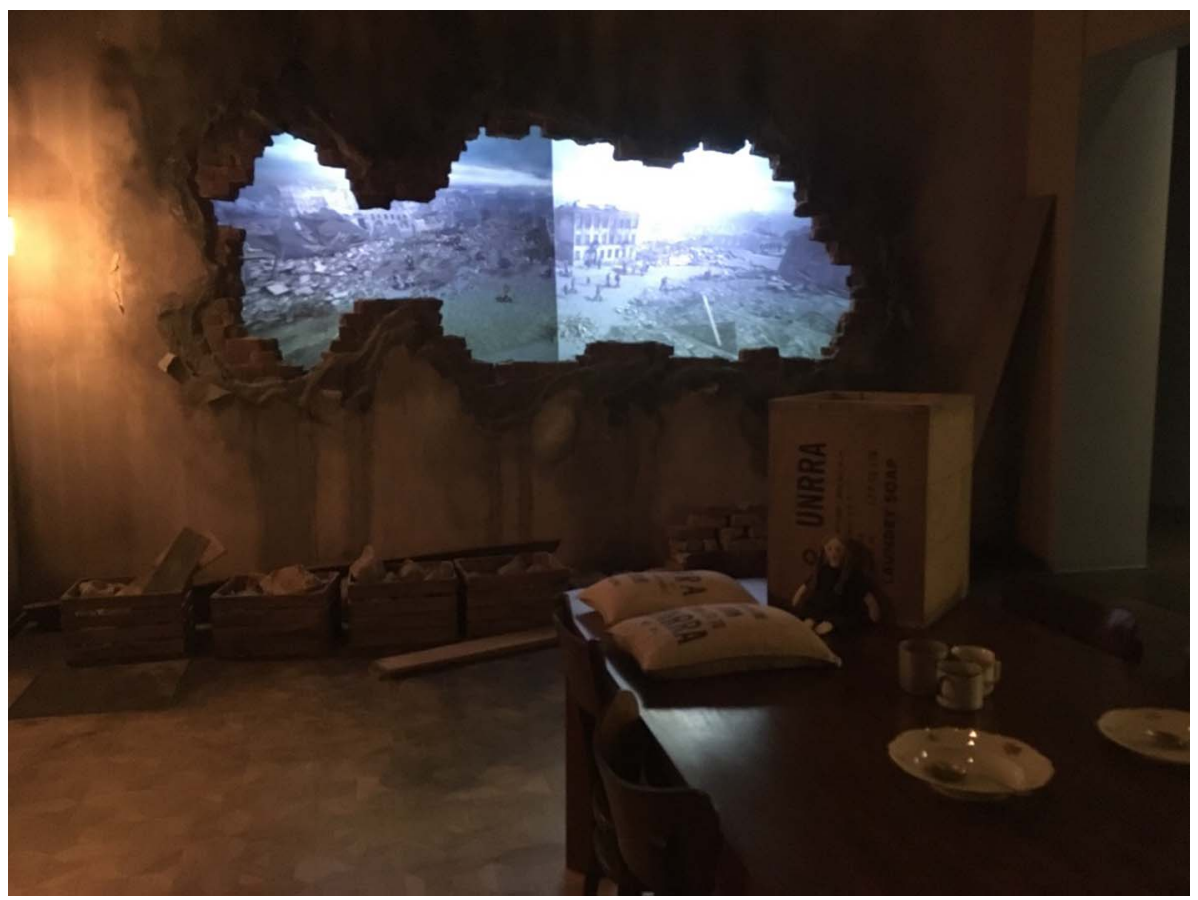

FIGURE 1. An example of a copy-and-paste solution in Polish digital museums: a destroyed wall from a Polish building dating to the World War II period. The hole is filled with a multimedia screen showing a ruined city. Museum of the Second World War in Gdańsk. Photograph by Monika Stobiecka.

implementation of digital tools facilitates communication with visitors (although he does not explain what this entails) and gives the exhibition a "reliability" in the eyes of younger audiences (Ołdakowski 2019:76).

New museums that follow this scheme are historic, and they tend to focus on the recent past-namely on two periods that crucially shaped Polish identity: World War II (Kowal and Wolska-Pabian 2019) and Communism (Ziebińska-Witek 2018). The narrative and aesthetic pattern they use is clichéd for two reasons. First of all, to increase visitor numbers, they typically follow the standard "narrative display" created by the Warsaw Rising Museum, seeking to mimic their narrative to achieve success with audience attendance. Secondly, a handful of companies-namely New Amsterdam, Adventure Multimedialne Muzea, and Nizio Design International-rule the Polish digital exhibitions market. For instance, one company specializes in creating multimedia tram wagons that visitors enter to enjoy a video or play on a tablet. If the museum tells the story of prewar times, the wagon is designed as if from the 1920s. If it deals with Communism, the same wagon is stylized as from the 1960s. Even though they are far from original, reproducing only known solutions (Figure 1), these digital displays are generously financed by state authorities, who, in many cases, offer special funding programs for digital culture. A visible "digital preference" of the government results in a further increase of rehashed digital exhibitions and museums in Poland, even though many scholars openly criticize them (Kowal 2019; Ziębińska-Witek 2014, 2018).

More and more museums (including archaeological ones, e.g., Rynek Underground in Kraków, Museum of Archaeology and
History in Elblag, Piast Tower in Opole) are turning digital, following the same narrative display approach and hoping to attract more visitors. In the end, however, they struggle with familiar criticisms: they are accused of presenting visions of the past that are not believable, depriving the collections of material objects, and offering "flat experiences" that lack educational value. In contrast, the exhibition that I discuss below rejects the standardized pattern and creates an original solution for archaeological artifacts.

\section{DIGITALLY EXPLORING THE MATERIAL TREASURES OF PERU}

The temporary exhibition at the State Ethnographic Museum in Warsaw, Treasures of Peru: The Royal Tomb at Castillo de Huarmey, took place between December 15, 2017, and May 27, 2018 (Giersz and Przadka-Giersz 2018; Giersz and Przadka-Giersz, eds. 2018). It grew out of a collaboration between the Castillo de Huarmey Archaeological Project; the State Ethnographic Museum in Warsaw; the National Museum of Archaeology, Anthropology, and History of Peru in Lima; the Ministry of Culture in Peru; and the Polish Society of Latin-American Studies. Originally displayed in Lima, the exhibition traveled to Poland, where it was prepared together with the architectural studio Medusa Group and the graphic studio DEM Interactive. It presented finds from the archaeological site of Castillo de Huarmey, where an international archaeological mission led by Miłosz Giersz and Patrycja Przadka-Giersz has been conducting long-term research. The spectacular uncovering of an untouched royal tomb has been widely recognized as the most important discovery of 2013, as 
described by the American magazine Archaeology. It was later featured as the cover story on National Geographic magazine's June 2014 issue. The exhibition consisted of four spacious rooms presenting the history of the site and findings through a variety of analog and digital exhibits. Visitors would enter the display and find themselves in a wide room, whose design imitated the natural landscape of the archaeological site's surroundings. The floor was covered with gritted beige sand, and the visitors moved on it on a wooden track. Irregularly placed wooden boxes with showcases presented artifacts excavated from Castillo de Huarmey. Above the heads of visitors, there was a flat ceiling made of white blotting paper. This aesthetic installation resembled the lower horizon in Peru (Figure 2). Colors, installations, and showcases created a convincing effect of immersion, where no digital tools were needed. The display was advertised as multimedia in nature, which might have led visitors to expect the standard structure of digital immersion that is popular in Poland, where one enters a dark room and is immediately bombarded by many stimuli. Here, the opposite happened. The interplay between all the elements (decorations, artifacts, and natural materials such as sand and wood) smoothly introduced visitors into the realm of archaeological investigations. Personal linkages with the archaeologists, whose photograph was presented in the first room, were also used to create a more intimate connection between the visitors and the curators/archaeologists.

The second room was designed to host a digital showcase. There were digital reconstructions, visualizations, and a virtual reality experience (a tour of the archaeological site). This digital room was purely informative, attractively presenting historical and archaeological facts. Instead of lengthy texts, visitors were given a chance to see a digital archaeological workshop (i.e., GIS-related materials such as satellite photos, a movie presenting archaeological works with drones, 3D scanners, etc.) and a variety of other materials visually explaining work at the archaeological site. When entering this room during the guided tours organized by Giersz and Przadka-Giersz, the digital archaeological specialists Marta Bura and Janusz Janowski would join the tour and explain in detail all the materials and technologies used at the excavations.

The next room, a black cube, hosted the most spectacular result of the archaeological studies at the site to date-the hyperrealistic facial reconstruction of a Wari queen (Figure 3). The original model was accompanied by two screens, one of them presenting a moving reconstruction of the queen's head, the other showing an archaeological visualization of the reversed taphonomical process.

The greatest innovation of this exhibition, however, was waiting for visitors in the last room. Here, visitors entered to see many wooden boxes stacked against the walls (Figure 4) and a wooden structure, resembling the Castillo de Huarmey mud-brick and stone architecture, placed in the center of the room (Figure 5). The intent was to allow visitors to climb the structure and look for $Q R$ codes. After scanning a code, visitors could retrieve textual and/or visual information (photos, movable models, short videos showing artifacts in different stages of exploration or conservation accompanied by short descriptions, etc.; Figure 6) from the official website's database, which is still accessible (Skarby Peru 2017), as is the virtual tour (Peru Virtual Exhibition 2017). It should be mentioned that the information was diverse and did not follow a predictable pattern of presentation. Visitors were encouraged to explore the material content of the room (search for the $Q R$ codes), as well as the digital content of the database. What could be a better means to show archaeology than to motivate the public to uncover artifacts and information? Even though QR

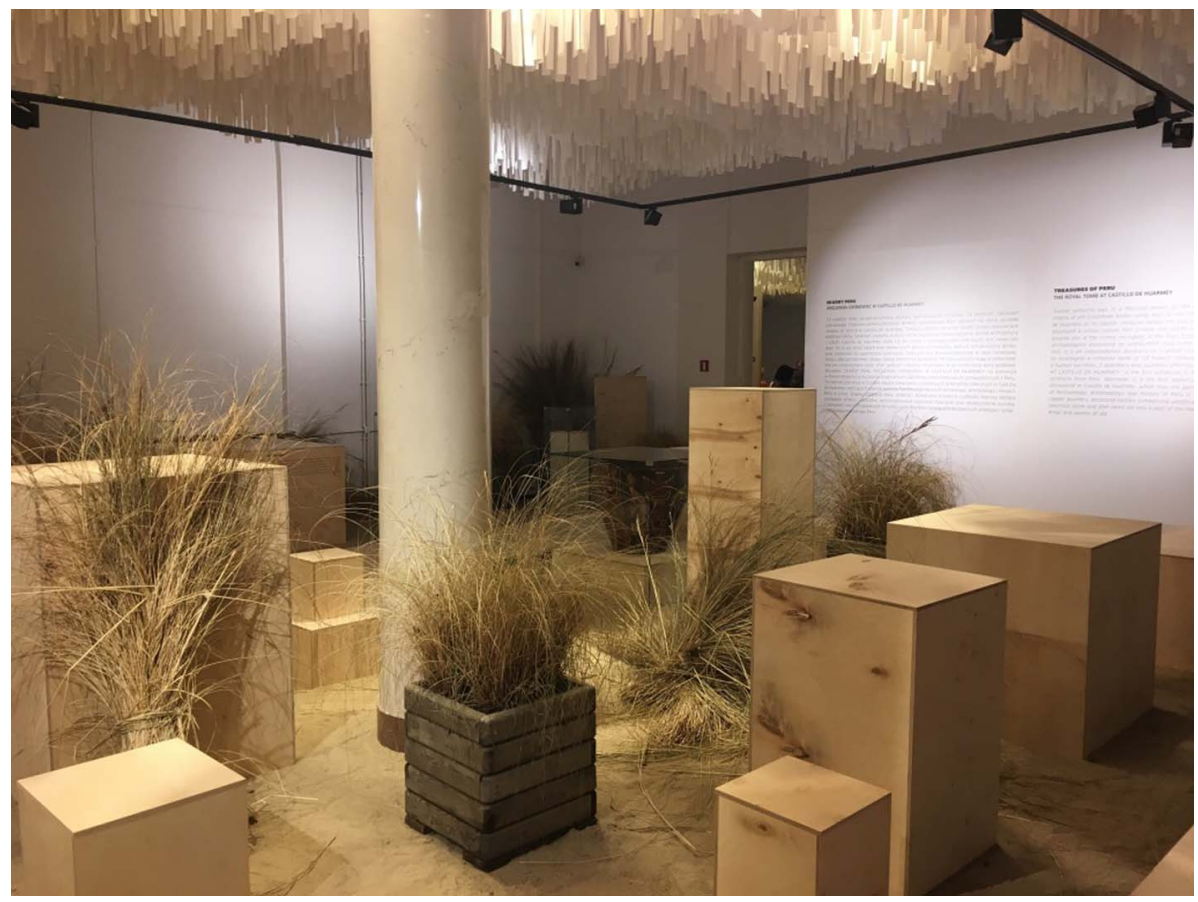

FIGURE 2. The passage from the first to the second room of the exhibition Treasures of Peru: The Royal Tomb at Castillo de Huarmey, State Ethnographic Museum in Warsaw. Photograph by Monika Stobiecka. 


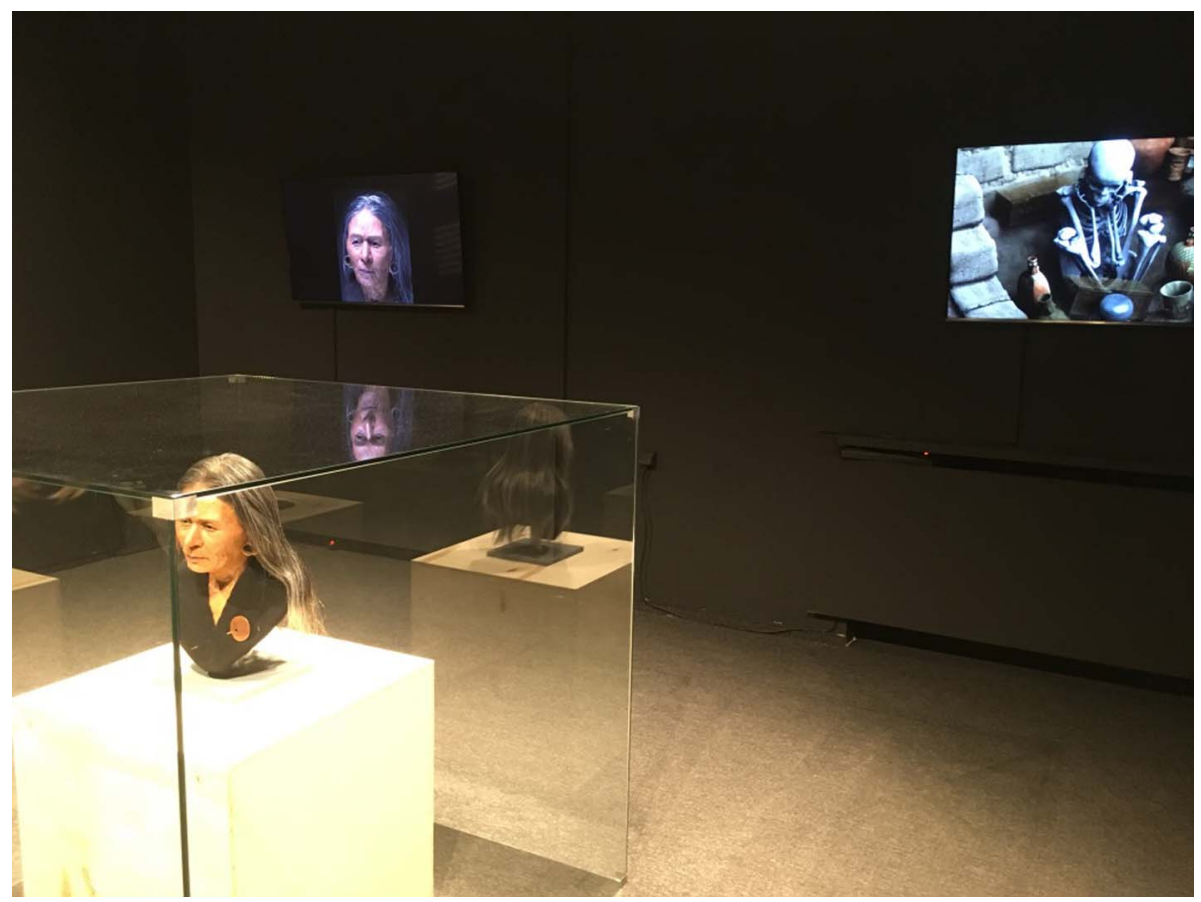

FIGURE 3. Facial reconstruction of the Huarmey Wari Queen accompanied by a virtual model (on the left) and the reconstruction of the archaeological context (on the right). State Ethnographic Museum in Warsaw. Photograph by Monika Stobiecka.

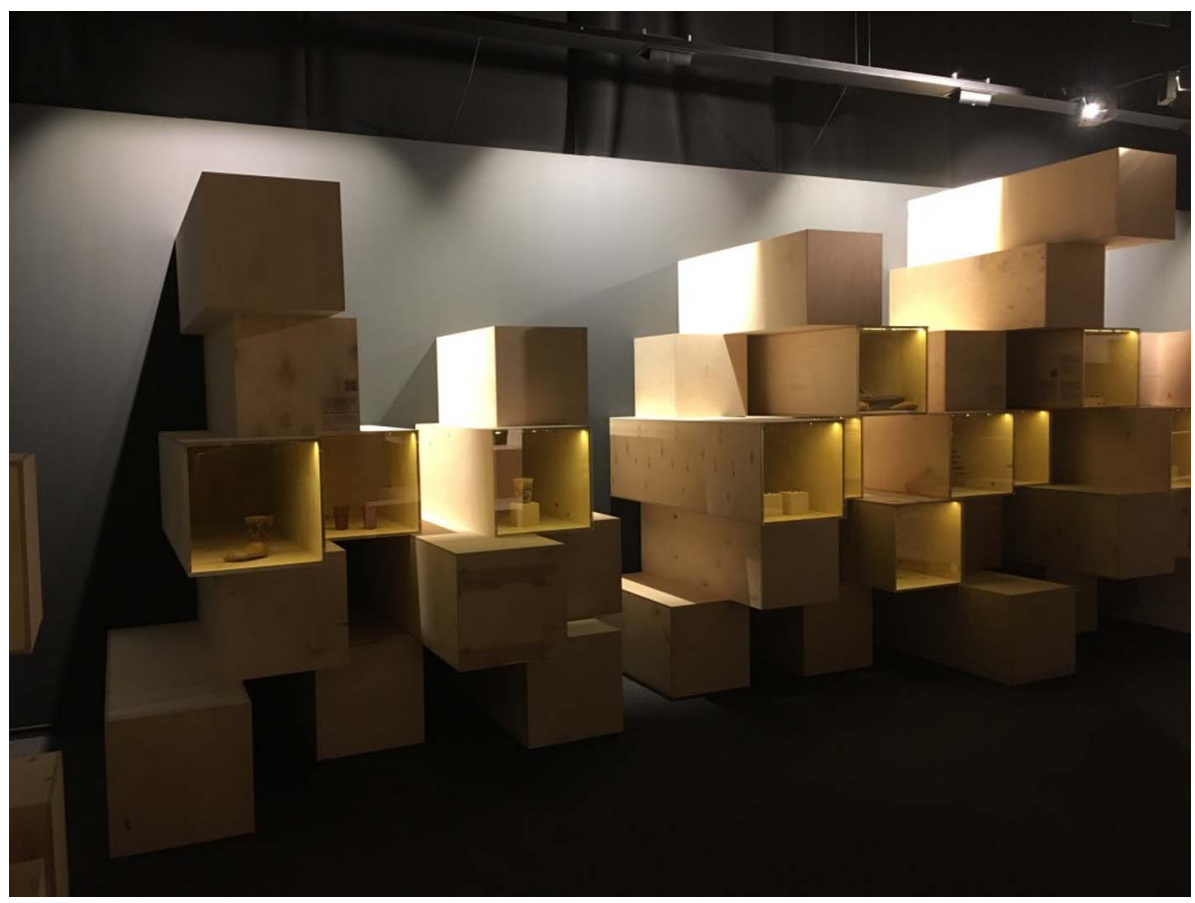

FIGURE 4. Wooden showcases placed against the walls with original artifacts and QR codes irregularly positioned around the displays. State Ethnographic Museum in Warsaw. Photograph by Monika Stobiecka.

technology is one of the simplest methods to provide digital content to tangible objects, curators proved that it could be used in an engaging way. Visitors, whether children or adults, were visibly enjoying the exhibit, wandering around the boxes, climbing the structure, and searching for codes that would tell them more about the objects. In this sense, I believe that the last room 


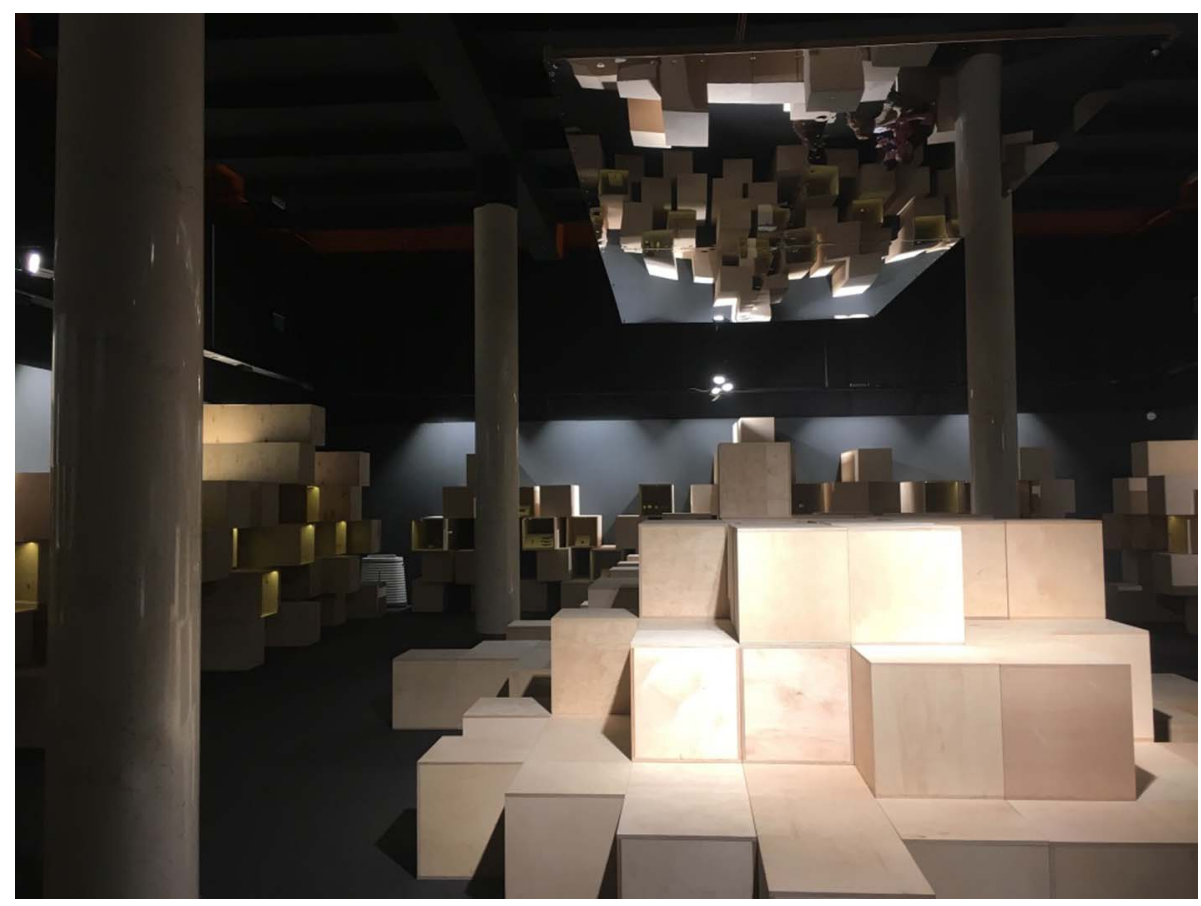

FIGURE 5. The wooden structure with hidden artifacts and QR codes that was often crowded with visitors acting as explorers. State Ethnographic Museum in Warsaw. Photograph by Monika Stobiecka.

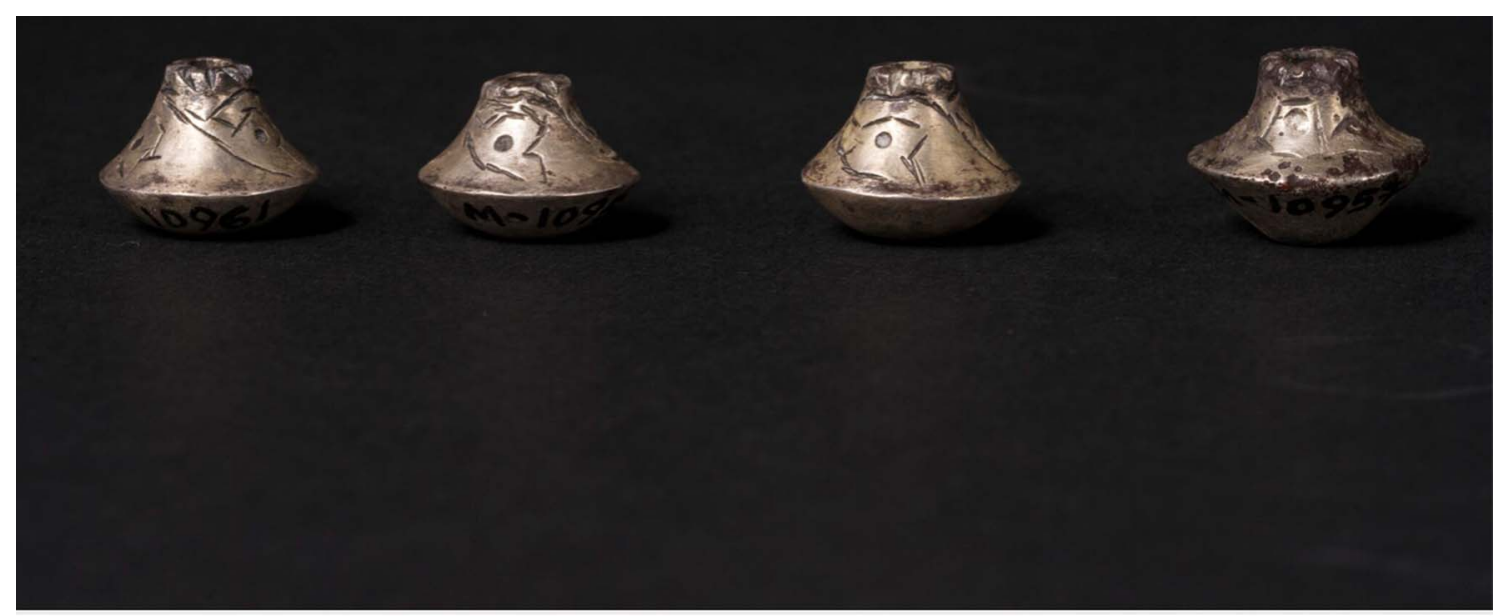

SPINDLE WHORLS

五

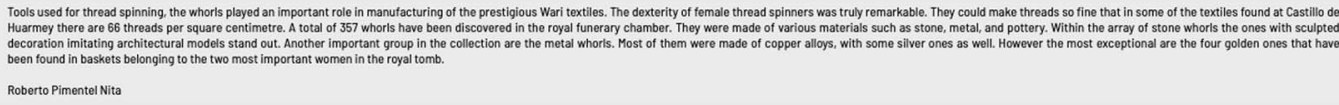

coprentr 2017

FIGURE 6. An example of an entry redirected from a QR code scan: short information featuring a high-quality, aesthetic photograph. Accessed at http://www.skarbyperu.pl/63/en/. State Ethnographic Museum in Warsaw.

presented the essence of archaeology while effectively escaping from the typical digital display pattern in Poland.

I interviewed Przadka-Giersz and Giersz, the archaeologists who excavated Castillo de Huarmey, about how they handled the preparation of the display. Encouraged by the director of the State Ethnographic Museum, they invited a renowned professional architect, Przemo kukasik, to be responsible for the exhibition's aesthetics. Furthermore, they collaborated with specialists in digital archaeology so as to avoid copy-and-paste patterns 
common to other Polish museums. While the architect focused on the aesthetics and design, inspired by information provided by scholars, the archaeologists prepared the content, including information panels, descriptions on the website accessed through QR codes, and guided tours. In contrast to typical Polish digital displays prepared by outsourced companies with little influence by scholars, it is no surprise that Treasures of Peru: The Royal Tomb at Castillo de Huarmey was so strikingly coherent. The exhibition also differed from other displays in terms of aesthetics. Instead of immersion in dark cellars, visitors were given a chance to grasp the natural environment of Peru.

\section{CONCLUSIONS}

Many digitally mediated exhibitions fail at providing new types of narration, merely exchanging the analog for the digital. In contrast, the exhibition discussed here was prepared by scholars, an architect, and digital specialists, and it offered a holistic, engaging, and original experience based on scientific and professional content. The curatorial staff did not seek ready-made solutions provided by external companies. Instead, they worked closely with the material collections, not simply with immaterial "content" (cf. Hanussek 2020). Technology that was used to engage visitors was not the latest and most innovative, but rather an attractive, digitally supported display with a coherent vision resulting from a fusion of different perspectives. Consequently, Treasures of Peru: The Royal Tomb at Castillo de Huarmey proved that thinking about digital archaeological exhibitions should start not with technologies but rather with multiple conceptual insights. Only by deploying different views can digital archaeological museums start a critical reflection upon the challenges posed by new technologies.

\section{Acknowledgments}

I would like to express my gratitude to Miłosz Giersz and Patrycja Przadka-Giersz for personal communication and an exhaustive explanation of the display's objectives. Marta Bura, a digital archaeologist who participated in the works, was also an important source of information about the digitization techniques, and I wish to thank her here. I would like to thank Sara Perry for commenting on a draft version of this review.

\section{REFERENCES CITED}

\section{Classen, Constance, and David Howes}

2006 The Museum as Sensescape: Western Sensibilities and Indigenous Artifacts. In Sensible Objects: Colonialism, Museums and Material Culture, edited by Chris Gosden, Elisabeth Edwards, and Ruth B. Phillips, pp. 199222. Berg, Oxford.

Copplestone, Tara, and Daniel Dunne

2017 Digital Media, Creativity, Narrative Structure and Heritage. Internet Archaeology 44. DOI:10.11141/ia.44.2.

Favro, Diane

2013 To Be or Not To Be in Past Spaces: Thoughts on Roman Immersive Reconstructions. In Re-Presenting the Past: Archaeology through Image and Text, edited by Sheila Bond and Stephen Houston, pp. 151-168. Oxbow Books, Oxford.
Folga-Januszewska, Dorota, and Paweł Kowal

2019 Definicja muzeum narracyjnego. In Muzeum i zmiana: Losy muzeów narracyjnych, edited by Paweł Kowal and Karolina Wolska-Pabian, pp. 4950. Universitas, Warszawa-Kraków, Poland

Geismar, Heidi

2018 Museum Object Lessons for the Digital Age. UCL Press, London.

Giersz, Miłosz, and Patrycja Prządka-Giersz (editors)

2018 Skarby Peru: Królewski grobowiec w Castillo de Huarmey. Polskie Towarzystwo Studiów Latynoamerykanistycznych, Warsaw.

Giersz, Miłosz, and Patrycja Przadka-Giersz

2018 Skarby Peru w Państwowym Muzeum Etnograficznym w Warszawie, czyli słów kilka o pokłosiu interdyscyplinarnych badań prekolumbijskiego ośrodka Castillo de Huarmey/Treasures of Peru in the National Ethnographic Museum in Warsaw, a Commentary on the Outcome of the Interdisciplinary Studies of Pre-Columbian Castillo de Huarmey. Nowa Etnografia/The New Ethnography 9/10:379-413.

Hanussek, Benjamin

2020 Enhanced Exhibitions? Discussing Museum Apps after a Decade of Development. Advances in Archaeological Practice 8:206-212.

Kidd, Jenny

2014 Museums in the New Mediascape: Transmedia, Participation, Ethics. Ashgate, Farnham, United Kingdom.

Kowal, Paweł

2019 Społeczny, cywilizacyjny i polityczny kontekst polskiego boomu muzealnego. In Muzeum i zmiana: Losy muzeów narracyjnych, edited by Paweł Kowal and Karolina Wolska-Pabian, pp. 31-48. Universitas, Warszawa-Kraków, Poland.

Kowal, Paweł, and Karolina Wolska-Pabian (editors)

2019 Muzeum i zmiana: Losy muzeów narracyjnych. Universitas, Warszawa-Kraków, Poland.

Ołdakowski, Jan

2019 Dlaczego powstają muzea historyczne narracyjne? In Muzeum i zmiana: Losy muzeów narracyjnych, edited by Paweł Kowal and Karolina Wolska-Pabian, pp. 73-78. Universitas, Warszawa-Kraków, Poland. Perry, Sara

2015 Crafting Knowledge with (Digital) Visual Media in Archaeology. In Material Evidence: Learning from Archaeological Practice, edited by Robert Chapman and Allison Wylie, pp. 189-210. Routledge, London. Skarby Peru

2017 Warszawa, Państwowe Muzeum Etnograficzne, Wystawa Skarby Peru. Electronic document, http://www.skarbyperu.pl, accessed May 18, 2020.

Peru Virtual Exhibition

2017 3D Scanners Lab, Peru Virtual Exhibition. Electronic document, http:// www.3dscannerslab.eu/peruvirtualexhibiotion/?fbclid=IwAR2OS muaoMyHNV1Zsdp_nTDtt3dytruHj-xIVW0pfFpz5y43zLq74I2CtyM, accessed May 18, 2020.

Vergo, Peter

1989 The Reticent Object. In The New Museology, edited by Peter Vergo, pp. 41-59. Reaktion Books, London.

Ziębińska-Witek, Anna

2014 Totalitaryzm w nowych muzeach historycznych. In Historia Polski od-nowa: Nowe narracje historii i muzealne reprezentacje przeszłości, edited by Robert Kostro, Kazimierz Wóycicki, and Michał Wysocki, pp. 26-44. Muzeum Historii Polski, Warsaw.

2018 Muzealizacja komunizmu w Polsce i Europie środkowo-wschodniej. Uniwersytet Marii Curie-Skłodowskiej, Lublin, Poland.

\section{AUTHOR INFORMATION}

Monika Stobiecka — Faculty of "Artes Liberales," University of Warsaw, ul. Dobra 72 00-312, Warsaw, Poland (m.stobiecka@uw.edu.pl) 